\title{
Okul öncesi öğretmen adaylarının bilişötesi farkındalıkları ile duygusal zeka özellikleri arasındaki ilişkinin incelenmesi
}

\author{
The relationship between metacognitive awareness and emotional \\ intelligence of preschool teacher candidates
}

\author{
Asude Balaban Dağal ${ }^{1}$, Beyza Hamamc1 ${ }^{2}$, Kübra Yayla ${ }^{3}$
}

\begin{abstract}
Makale Geçmişi
Geliş :22 Ocak 2020

Düzeltme :18 Temmuz 2020

Kabul :5 Ağustos 2020
\end{abstract}

\section{Makale Türü}

Arastrma Makalesi

\section{Article History}

Received :22 January 2020

Revised :18 July 2020

Accepted :5 August 2020

\section{Article Type}

Research Article
Öz: Bu araştırmanın amacı okul öncesi öğretmen adaylarının bilişötesi farkındalıkları ile duygusal zeka özellikleri arasındaki ilişkinin incelenmesidir. Nicel araştırma yöntemlerinden, ilişkisel tarama modeli kullanılmıştır. Araştırmanın çalışma grubunu, devlet ve vakıf üniversitelerinde okul öncesi öğretmenliği lisans eğitimine devam etmekte olan $244^{\prime}$ ü kız $16^{`}$ ss erkek ve cinsiyetini belirtmeyen bir kişi olmak üzere toplam 261 öğretmen adayı oluşturmaktadır. Öğretmen adaylarını bilişötesi farkındalıklarını ölçmek amacıyla Bilişötesi Farkındalık Envanteri ve duygusal zeka özelliklerini ölçmek amacıyla Duygusal Zeka Özelliği Ölçeği kullanılmıştır. Yapılan analizlere göre bilişötesi farkındalıkları ve duygusal zeka puanlarının sınıf düzeyi, üniversite türü ve mezun olunan lise türü değişkenlerine göre farklılaşmadığı, üniversiteye yerleşilen puan türü değişkenine göre farklılaştı̆̆1 görülmüsstür. Korelasyon analizleri sonucuna göre; bilişötesi farkındalıkları ve duygusal zeka özellikleri arasında ve okul öncesi öğretmen adaylarının bilişötesi farkındalıkları ile duygusal zeka özellikleri düzeylerinin bilişötesi farkındalıkları ile duygusal zeka özelliklerine iliş̧kin algıları arasında pozitif yönlü anlamlı bir ilişki olduğu ortaya çıkmıștır. Anahtar Kelimeler: Bilişötesi, Duygusal zeka, Öğretmen adayı

Abstratct This research was aimed at analysing the correlation between metacognitive awareness and emotional intelligence characteristics of preschool teacher candidates. Correlation survey model as a quantitative research method has been used. The work group of the research included a total of 261 teacher candidates consisting of 244 females, 16 males and one person with unstated gender who have been receiving undergraduate education in the field of preschool teaching at public and foundation universities. Metacognitive Awareness Scale was used for measuring the metacognitive awareness of teacher candidates and Emotional Intelligence Scale for measuring their emotional intelligence characteristics. At the end of the analyses it was found that metacognitive awareness and emotional intelligence scores do not vary depending on the grade level, the type of university and the type of graduated high school, but they did vary depending on the type of scores based on which they had entered university. The correlational analyses results indicated a significant positive correlation between metacognitive awareness and emotional intelligence characteristics and between the metacognitive awareness and emotional intelligence characteristics of preschool teacher candidates and their perceptions of metacognitive awareness and emotional intelligence characteristics.

Keywords: Metacognition, Emotional intelligence, Teacher candidate

\footnotetext{
* Bu çalışma 30 Kasım - 1 Aralık 2019 tarihleri arasında TED Üniversitesi’nde gerçekleşen III. Uluslararası Öğretmen Eğitimi ve Akreditasyon Kongre'sinde sözlü bildiri olarak sunulmuştur.

Başlıca Yazar: Beyza Hamamc1, İstanbul Üniversitesi-Cerrahpaşa, Hasan Âli Yücel Eğitim Fakültesi, Temel Eğitim Bölümü, İstanbul

${ }^{1}$ Marmara Üniversitesi, Atatürk Eğitim Fakültesi, Temel Eŭitim Bölümü, asudebd@marmara.edu.tr, ORCID: 0000-0002-9527-5335

2 İstanbul Üniversitesi-Cerrahpaşa, Hasan Âli Yücel Eğitim Fakültesi, Temel Eğitim Bölümü, beyzahamamci@istanbul.edu.tr, ORCID: 0000-00019926-4345

${ }^{3}$ Marmara Üniversitesi, Eğitim Bilimleri Enstitüsü, Temel Eğitim Bölümü, kubrayayla@marun.edu.tr, ORCID: 0000-0001-9592-8466
} 


\section{SUMMARY}

\section{Introduction}

In recent years, education programs and teachers have had success in improving the self-regulation skills of students (Yaralı and Aytar, 2017; Çiltaş, 2011). Self-regulation skills consist of the management of behavioral, cognitive, and emotional aspects. Two concepts related to and important for self-regulation skills are emotional intelligence and metacognition. The concept of metacognition is defined differently by many researchers. According to Flavell (1979), who conducted the first studies in this field, metacognition is the ability of an individual to control his/her knowledge of his/her own cognitive processes as well as to control those processes.

Metacognition is known to be an important factor in reading comprehension, communication, attention, memory, problem-solving, self-learning, etc. (Flavell, 1979). Therefore, the use of metacognition contributes positively to the field of education. Individuals who have metacognitive skills become aware of their own learning processes and styles. Development of this awareness has an impact on the individual's success (Doğan, 2013). The effectiveness of education-measured by student performance-is also related to the metacognitive skills of teachers. Teachers must make conscious and purposive decisions when planning and working with students (Duffy, Miller, Parsons ve Meloth, 2009).

Emotional intelligence is a relatively new concept though it does have origins in Darwin's theory of the basis of survival. Salovey and Mayer, who introduced the concept to the literature, describe an individual with emotional intelligence as having the following five main traits: being aware of emotions; coping with emotions; motivating oneself; realizing the emotions of others; and being able to maintain relationships (Salovey and Mayer, 1990). Emotional intelligence can thus be defined as a concept that refers to being aware of, understanding, and controlling one's own emotions as well as understanding and recognizing the emotions of others. This information is then used for the success of oneself and others.

Metacognition and emotional intelligence are mainly related to an individual's self-regulation skills. Self-regulation involves an individual's planning of his/her own emotions, thoughts, and behaviors and regulating them through feedback to achieve his/her goals (Zimmerman, 2000). The metacognition theory of Wells (2002) focuses on an individual thinking about their thoughts in an emotion regulation strategy. Given these definitions and descriptions, it can be surmised that metacognition, which is an important part of the cognitive components of self-regulation and emotion regulation, is associated with emotional intelligence. 
The use of emotions involves the ability to use emotions that help with certain cognitive initiatives such as reasoning, problem-solving, decision-making, and interpersonal communication (Brackett, Rivers, Shiffman, Lerner and Salovey, 2006). Further, several studies on the biological origin of metacognition and emotional intelligence have found that the frontal cortex of the brain is active in both (Krueger, et al., 2009; Fleming and Dolan, 2012). Taken together, these definitions, analysis, and findings suggest that emotional intelligence and metacognition are interrelated.

The main purpose of this study was to examine the relation between the metacognitive awareness and emotional intelligence skills of preschool teacher candidates. For this purpose, differentiations among the metacognitive awareness and emotional intelligence skills of teacher candidates were studied according to the following demographic attributes: class level; type of university; type of high school; type of undergraduate placement exam score; estimated values of emotional intelligence skills; and estimated values of metacognitive awareness.

\section{Method}

Correlational study was conducted. Data collection tools used during the study included "Personal Information Form"; "Metacognitive Awareness Inventory"; and "Emotional Intelligence Questionnaire - Short Form." The study group consisted of 261 students in the first or fourth grades of an undergraduate program for preschool teaching in a state or foundation university in the spring semester of the 2018-2019 academic year.

\section{Results}

The study found a positive and moderately significant relation between the metacognitive awareness and emotional intelligence skills of preschool teacher candidates. While the metacognitive awareness and emotional intelligence skills of teacher candidates showed no significant difference according to the variables of class level, university type, and high school type, there were significant differences according to the type of undergraduate placement exam score, estimated values of metacognitive awareness, and estimated values of emotional intelligence skills.

\section{Conclusion and Discussion}

This study suggested that the higher the metacognitive awareness-related scores of teacher candidates, the higher their scores of emotional intelligence. Another study has also found a significant positive relation between emotional intelligence and metacognition in terms of metacognitive awareness (Byzova and Perikova, 2019).

A positive low significant relation was found between the metacognitive awareness estimations and the metacognitive awareness inventory scores of the teacher candidates and their estimations of 
their emotional intelligence skills and emotional intelligence scores. It was also found that (where the teacher candidates were evaluated on the type of undergraduate placement exam score) the metacognitive awareness inventory and emotional intelligence scores showed a positive significant difference in favor of the teacher candidates who were replaced by the DGS (Dikey Geçiş Sınavi) type of score. Based on this finding, it can be said that the type of university placement score has an impact on the average metacognitive awareness and emotional intelligence scores. Candidates who showed differences were the candidates who earned associate degrees from Vocational Schools of universities and chose to continue their education in the undergraduate degree by fulfilling the associate degree achievement and DGS score criteria (ÖSYM, 2019).

Another finding of the study suggested that the metacognitive awareness inventory or emotional intelligence scores of the teacher candidates in the study group show no significant difference by the variable of university type. This result may indicate that the students who study in a preschool teaching undergraduate program have a similar profile regardless of university type, that the candidates who have chosen these schools have similar features, or that the university education causes the teacher candidates to gain similar characteristics (YÖK Atlas, 2019).

It has been found that the metacognitive awareness inventory and emotional intelligence scores of the teacher candidates show no significant difference according to the class level variable. While another study includes findings in favor of the fourth grade students when compared with the metacognitive awareness of the preschool teachers by the class level variation (Özsoy and Günindi, 2011), there are also findings suggesting that the scores of teacher candidates from the first and fourth grades are parallel (Demirel, Aşkın ve Yağc1, 2015).

Finally, it has been found that the metacognitive awareness scores and emotional intelligence scores in the study group demonstrated no significant differences according to the variable of high school type. This finding is consistent with those of other studies that show that there is no significant difference in the metacognitive awareness scores of teacher candidates based on the type of high school from which they graduated (Özsoy ve Günindi, 2011; Cihanoğlu, 2012; Demirel, Aşkıın ve Yağc1, 2015).

Researchers and practitioners may be given some suggestions as a result of this study. It is recommended for example, that studies be conducted with sample groups that show differences in predictor. Studies should also take into consideration the relation between metacognitive and emotional intelligence characteristics of the teacher candidates in terms of the moderately positive relation result obtained here. With respect to the result that no significant difference was found in terms of class level, it is recommended that practitioners implement training programs wherein 
teacher candidates can improve their emotional intelligence and metacognition skills during the education process and also conduct activities to raise awareness in this field. 


\section{GİRIŞ}

Eğitim, yaşamı değiştirmek için önemli bir güçtür. Onu algılayışımız ile eğitim, bakış açısı geliştirmemize olanak sağlayan en önemli araçlardan biri olmaktadır. Öğretmenler de kendi öğrenim geçmişleri ile bu sürecin önemli bir unsurudur. Ülkelerin geleceği eğitim sistemleri ile, eğitim sistemlerinin etkililiği çoğunlukla öğretmen niteliği ile belirlenmektedir (TEDMEM, 2018). Öğretmen niteliğinin ilk belirleyicileri, adayların lisans programlarına yerleşme süreçleri ve lisans eğitimlerinde aldıkları ders içerikleri olarak görülebilir. Türkiye'de öğretmenler; merkezi yerleştirme sistemi (bakınız; ÖSYM) ile lisans programlarına yerleşerek öğretmenlik meslek bilgisi, alan eğitimi ve genel kültür olarak belirlenen üç alandan dersler alarak mezun olmaktadır. Meslek bilgisi dersleri incelendiğinde çoğunlukla kuramsal bilgilerin bulunduğu ve uygulama ağıllıklı olan iki “Öğretmenlik Uygulaması” derslerinin bulunduğu görülmektedir (Orta Doğu Teknik Üniversitesi Eğitim Bilimleri Bölümü, 2018). Okul Öncesi Öğretmenliği Lisans Programının alan bilgisi dersleri göz önünde bulundurulduğunda ise; 2018 yllında yayınlanan program ile ders içeriklerinin kuramsal boyutta bulunduğu görülmektedir (Yüksek Öğretim Kurumu, 2018). Tüm bunlar göz önünde bulundurulduğunda; öğretmen eğitimi lisans programının, öğretmen adaylarına çoğunluk ile kuramsal bilgileri edinebileceği içerikte düzenlendiği görülmektedir.

Türkiye'de de eğitimin kalitesi, öğretmenlerin uygulamaya yönelik becerileri ve buna bağlı olarak öğretmen adaylarının fakültelerde aldıkları eğitim tartışmalı konulardan biridir. Bu nedenle; öğretmen yetiştirme programlarına yerleşen adayların profilleri, eğitim süreçleri ve öğretmenlik deneyimleri sıklıkla araştırmalara konu olmaktadır (Işık, Çiltaş ve Baş, 2010). Değisşen süreç içerisinde mesleğine devam etmekte olan öğretmenin ve öğretmen adaylarının gelecekte sınıf içerisindeki rolleri ve öğrenciye kazandırması beklenen beceriler farklılaşmaktadır. Son y1llarda eğitim programlarının ve öğretmenlerin öğrencilerin öz düzenleme becerilerini geliştirmeye yöneldiği gözlemlenmektedir (Yaralı ve Aytar, 2017; Çiltaş, 2011). Öz düzenleme becerileri davranışsal, bilişsel ve duygusal düzenleme boyutlarından oluşmaktadır. Bu bilgiler ışığında öz düzenleme becerilerini kapsayan duygusal zeka kavramı ve öz düzenleme becerilerine etki eden üst biliş/bilişötesi kavramı önemli özelliklerden ikisidir. Bu becerilerin öğrenciye kazandırılmasında öğretmenin ve öğretmen yetiştirme programında öğrenim gören öğretmen adaylarının rol model davranışları ve bu alandaki kendi becerileri merak oluşturmaktadır.

Bu bağlamda bilişötesi ile ilgili yapılmış çalışmalar incelendiğinde kavramın; psikoloji, eğitim, felsefe ve bilişsel bilimler alanlarında çeşitli boyutları ile ele alındığı görülmektedir. İngilizce alan yazında 'metacognition' ifadesi ile yer alan kavram Türk alan yazınında biliş üstü, bilişötesi ve üst biliş ifadeleri ile kullanılmıştır (bakınız; Akın, Abacı ve Çetin, 2007; Baş ve Özturan Sağırlı, 2017; Oktay 
ve Özcan, 2017). Mevcut çalışmada, kullanılan ölçeğin isminde bilişötesi ifadesine yer verildiği için makalenin tamamında bu ifadeye yer verilmiştir. Alanda ilk çalışmaları yapan araştırmacı Flavell'e (1979) göre bilişötesi, "bireyin kendi bilişsel süreçleri hakkında bilgisi ve bu süreçleri denetleyebilmesidir” şeklinde tanımlarken, Martinez (2006) bilişötesini düşüncenin izlenmesi ve kontrolü olarak tanımlamıştır. Karakelle (2016) ise insanın düşünceleri üzerine düşünme özelliklerini belirten ve kendini izleme ile öz düzenleme süreçlerini de içine alan bir yapı olarak açıklamıştır. Tanımların da değindiği üzere bilişötesi çok yüzlü ve kapsamlı bir kavramdır. Flavell (1979) bilişötesini; bilişin ve bilişsel görevlerin yapısına ilişkin bilgi ve bunların stratejilerini içeren bilişötesi bilgiler ve bireyin kendi bilişini izlemesi, kontrol etmesi ile organizasyonunu içeren bilişötesi deneyimler olarak ikiye ayırmıştır. Benzer bir ayrım Brown tarafından biliş bilgisi ve bilişin düzenlenmesi başlıklarında yapılmıştır (Brown, 1987). Dunlosky ve Metcalfe ise bilişötesi bilgi, bilişötesi izleme ve bilişötesi denetleme olarak üç boyutlu bir kavram olarak belirtmiştir (akt. Karakelle, 2016).

Bilişötesinin okuduğunu anlama, iletişim, dikkat, bellek, problem çözme ve kendi kendine öğrenme gibi alanlarda önemli bir etmen olduğu bilinmektedir (Flavell, 1979). Bu özellikleri ile bilişötesinin kullanımı eğitim alanına olumlu katkılarda bulunmaktadır. Bilişötesi özelliklere sahip bireyler kendi öğrenme bilgilerinin ve stillerinin farkına varırlar. Bu farkındalığın gelişmesi kişinin başarısı üzerinde etkilidir (Doğan, 2013). 1970’li yıllarda yapılıış çalışmalar bilişötesindeki eksiklik nedeniyle öğrencilerin başarısız veya performanslarının düşük olduğunu göstermiştir. Farklı çalışmalarda bilişötesi becerilerin öğretilmesinin öğrencilerin öğrenmelerinin artmasına destek olduğu bulunmuştur (akt. Tüysüz, Karakuyu ve Bilgin, 2008). Öğrenci performansı üzerinden ölçülen eğitimin etkililiğinin öğretmenlerin bilişötesi özellikleri ile ilgili olduğu da düşünülmektedir. Öğretmenler planlama yaparken ve öğrenciler ile çalışırken bilinçli ve amaçlı kararlar vermelidir (Duffy, Miller, Parsons ve Meloth,2009). Bu durumlar göz önüne alındığında öğretmenden beklenen sınıf içerisinde çocukların bu becerilerini geliştirebilmesi için farkındalık oluşturmasıdır (Doğan, 2013). Bu bilincin öğretmenin yetiştirilmesinden itibaren gelişmesi eğitime olumlu katkılar sağlayacaktır. Bu becerileri gelişmiş olan öğretmenlerin öğrencilerinde de bu becerileri geliştirmeye yönelik stratejileri kullandıkları bilinmektedir (Imel, 2002; Özcan, 2007). Bununla beraber bilişötesi beceriler öğretmenlerin problem çözme, öğrenme, strateji belirleme ve öğrencilerin öğrenmelerini sağlamada anlık kararlar verebilme durumlarında önemli olmaktadır (Duffy, Miller, Parsons ve Meloth, 2009). Yurt dışında öğretmen adaylarının ve öğretmenlerin bu becerilerini geliştirmelerine yönelik çalışmalar yapılmıştır (bakınız; Gunzenhauser, Lindner, Harris ve Kersting, 1994). Bu çalışmanın hedeflerinde; bireyin kendi kaynaklarının sınırlanının tespit edilmesi, bireyin kaynaklarını arttırabilmek için öğrenme tekniklerini geliştirebilmesi ve ihtiyaçlarına yönelik olarak bireyin kendi 
kaynaklarını geliştirmesi yer almaktadır. Bu hedefler doğrultusunda ders içerikleri düzenlenmiş, seminer etkinlikleri yapılmış ve teknoloji dersleri verilmiştir. Türkiye'de bu kapsamda yapılmış bir çalışma bulunmamaktadır. Türkiye'de eğitim alanında bilişötesi ile ilgili yapılan çalışmalar 2002 yılında (Çetinkaya, Erktin, 2002) başlaması ile beraber 2011 yılından itibaren hızlı bir artış göstermektedir. Bu çalışmaların çoğunluğu bilişötesi bir özellik ve farklı özellikler arasındaki ilişkiye yönelik ve genellikle öğretmen adayları ile yapılmış çalışmalardır (Baş ve Özturan Sağırlı, 2017). Özsoy ve Günindi'nin (2011) yaptığı çalışmada okul öncesi öğretmen adaylarının orta-üst düzeyde bilişötesi farkındalığa sahip olduğu ve bu farkındalığın farklı sınıf düzeylerinde anlamlı düzeyde farklılaştı̆̆ bulgulanırken mezun olunan lise türü ve cinsiyet değişkenlerinde anlamlı bir farklılık gözlenmediği bulgulanmıştır.

Bireyin gerek sosyal gerek akademik yaşantısında her ne kadar biliş önemli görülse de önemli görülen bir diğer kavram ise duygusal zekadır. Duygusal zekanın kökleri Darwin'in hayatta kalma için temele aldığı görüssle başlamak ile beraber günümüzde görece yeni bir kavramdır. Kavramı literatüre kazandıran Salovey ve Mayer; duyguların farkında olma, duygularla başa çıkabilme, kendini motive etme, başkalarının duygularını fark etme ve ilişkileri yürütebilmek olmak üzere beş ana başlıkta açıklamıştır (Salovey ve Mayer, 1990). Goleman ise duygusal zekayı; öz farkındalık, öz düzenleme, motivasyon, empati ve sosyal becerilerden oluşan sosyal ve duygusal yetkinlikler olarak tanımlamaktadır (Goleman, 1999). Tanımlar göz önünde bulundurulduğunda duygusal zeka; kişinin kendi duygularının farkında olması, anlaması ve kontrol etmesi ile beraber başkalarının duygularını anlamayı ve farkında olmayı da kapsayan bu bilgileri kendi ve başkalarının başarısı için kullanmayı ifade eden bir kavramdir.

21. yüzyıl ile beraber insanın fonksiyonu yeni bir bakış açısı kazanmış ve gerek toplumsal durum gerek eğitim alanında duygusal ve sosyal yönelim oluşmuştur (Fernandez-Berrocal ve Ruiz, 2008). $\mathrm{Bu}$ durum eğitim programlarında da kendine yer bulmuş; duygusal alg1, duyguları anlama ve duygusal düzenleme gibi süreçler programlara dahil olarak duygusal zekanın akademik başarıyı ve okul iklimini geliştirdiği vurgulanmıştır (CASEL, 2019; Pellitteri ve Smith, 2007). Bununla beraber duygusal zekanın akademik başarı ile ilişkisini ve yordayıcı rolünü bulgulayan birçok çalışma bulunmaktadır (Mohzan, Hassan ve Halil, 2013; Barchard, 2003; Jaeger, Bresciani ve Ward, 2003). Öğrencinin başarısı ve öğrenmesindeki diğer bir etmen olarak öğretmen ve onun duygusal zeka Özelliği görülmüştür. Yapılan çalışmalar öğretmenlerin duygusal zeka özellikleri, sınıf disiplini ve öğrencilerin başarısı, öğrenme ve çalışma davranışları ile olumlu ilişkide bulunduğunu vurgulamaktadır (Valente ve Monteirove Lourenço, 2019; Curci ve Lancianove Soleti, 2014; Dolev ve Leshem, 2016). Öğretmen adaylarının duygusal zeka özellikleri ile ilgili yapılmış çalışmalarda; cinsiyet, yaş, farklı öğretmenlik branşları ve yerleşim yerlerine göre anlamlı farklılık göstermediği 
görülmektedir (Doğan Kılıç ve Önen, 2009). Bunların yanı sıra, duygusal zekanın elementlerinden biri olan duygu düzenleme becerisi yüksek olan öğretmenlerin mesleki doyumlarının daha yüksek ve tükenmişliklerinin daha düşük olduğu, duygularını kontrol etmede, yansıtılan duyguları anlamada ve iş arkadaşları ve yöneticilerine destek olmada daha başarılı olduğu görülmektedir (Brackett, Palomera, Mojsa-Kaja, Reyes ve Salovey, 2010). Türkiye'de öğretmenlerin duygusal zeka becerilerinin eğitilmesine ilişkin bir program uygulaması yapılmış ve öğretmenlere; duyguların farkına varmak, empati, etkili iletişim, motivasyon gibi başlıklarda on atölye çalışması ile Duygusal Zeka Becerileri Eğitim Programı uygulanmış, program sonunda öğretmen adaylarının duygusal zeka özelliklerinin anlamlı düzeyde arttığı bulunmuştur (Sarısoy ve Erişen, 2018).

Bilişötesi ve duygusal zeka temelde bireyin öz düzenleme becerisi ile ilişkili kavramlardır. Öz düzenleme kişinin hedefine ulaşması için duygu, düşünce ve davranışlarını planlaması ve geri bildirimler ile düzenlemesini içermektedir (Zimmerman, 2000). Duygu düzenleme; baskın duygunun ketlenmesi ve düzenlenmiş duygusal tepkinin sergilenmesidir (Gross, 2003). Bu tanımı ile duygu düzenleme; duygusal zeka kavramının kapsamında yer almaktadır. Bilişötesi ile öz düzenleme ise öğrenme temelinde birbiri ile ilişkilidir. Bu ilişki öğrenen kişinin bilişinin bilincinde olması ve bilişsel süreçlerini kontrol etmesi ile açıklanmaktadır (Zimmerman, 1989). Wells’in (2002) bilişötesi teorisi duygu düzenleme stratejisinde kişinin kendi düşüncesi üzerine düşünmesine odaklanmıştır. $\mathrm{Bu}$ tanımlar ve açıklamalar göz önünde bulundurulduğunda duyguların düzenlenmesi ile öz düzenlemenin bilişsel bileşenlerinin önemli bir parçası olan bilişötesinin duygusal zeka ile ilişkili olduğu tahmin edilmektedir.

Duygusal zeka kavramında birincil duygusal deneyimlere ek olarak insanların düşüncesi, duygularına yönelik algısı ve duygu yönetimi gibi ikincil süreçlerin eşlik ettiği görülmektedir. Ruh hali ile yargı arasındaki ilişkiyi değerlendirmek, iyi ruh halini korumaya çalışmak ve kötü ruh hali ile başa çıkarak onarmaya çalsşmak gibi ikincil süreçler duygusal durumlardaki orijinal düşünce deneyimi hakkında ikincil bir düşünceyi yansıttıkları için bilişötesidir (Brinol, Petty ve Rucker, 2006). Duygu kullanmak, akıl yürütme, problem çözme, karar verme ve kişilerarası iletişim gibi belirli bilişsel girişimlerde yardımcı olan duyguları kullanma yeteneğini içerir (Brackett, Rivers, Shiffman, Lerner ve Salovey, 2006). Bunun yanı sıra bilişötesinin ve duygusal zekanın biyolojik kökenine yönelik yapılmış çalışmalarda her ikisinde de beynin ön frontal korteksin aktif olduğu bulgulanmıştır (Krueger, ve diğerleri, 2009; Fleming ve Dolan, 2012). Tüm bunlar duygusal zeka ve bilişötesinin birbiri ile ilişkili olduğunu düşündürtmektedir.

$\mathrm{Bu}$ alanda yapılan çalışmalar incelendiğinde, öğretmen adaylarının bilişötesi farkındalıkları ile duygusal zeka özelliklerini temel alan çalışmaların sınırlı sayıda olduğu görülmektedir (Baş ve 
Özturan Sağırlı, 2017; Ünlü, Çevik ve Kurnaz, 2016; Byzova ve Perikova, 2019; Wheaton, 2012). Alan yazında yer alan bu sınırlılıktan yola çıkarak bu araştırmada, okul öncesi öğretmenliği lisans eğitimine devam etmekte olan öğretmen adaylarının bilişötesi farkındalıkları ile duygusal zeka Özellikleri arasındaki ilişkinin incelenmesi amaçlanmıştır. Bu amaç doğrultusunda "Okul öncesi öğretmen adaylarının bilişötesi farkındalıkları ile duygusal zeka özellikleri arasında anlamlı bir ilişki bulunmakta mıdır?” sorusu araştırmanın temel amacını oluşturmaktadır ve bu temel amaçtan yola çıkarak aşağıdaki alt amaçlara yanıtlar aranmıştır:

1. Okul öncesi öğretmen adaylarının bilişötesi farkındalık düzeyleri ile duygusal zeka düzeyleri arasında anlamlı bir ilişki bulunmakta mıdır?

2. Okul öncesi öğretmen adaylarının bilişötesi farkındalık düzeyleri ile bilişötesi farkındalıklarına ilişkin tahminleri arasında anlamlı bir ilişki bulunmakta mıdır?

3. Okul öncesi öğretmen adayların duygusal zeka düzeyleri ile duygusal zeka özelliklerine ilişkin bulundukları tahminleri arasında anlamlı bir ilişki bulunmakta mıdır?

4. Okul öncesi öğretmen adaylarının bilişötesi farkındalık düzeyleri üniversiteye yerleşme puan türü, sınıf düzeyi üniversite türü ve mezun olunan lise türü değişkenlerine göre farklılık göstermekte midir?

5. Okul öncesi öğretmen adaylarının duygusal zeka düzeyleri üniversiteye yerleşme puan türü, sınıf düzeyi üniversite türü ve mezun olunan lise türü değişkenlerine göre farklılık göstermekte midir?

\section{YÖNTEM}

\section{Araştırma Modeli}

$\mathrm{Bu}$ araştırma nicel araştırma desenlerinden ilişkisel tarama modeline uygun olarak yürütülmüştür. Korelasyonel çalışmaların; iki veya daha fazla değisskenin arasındaki ilişkinin herhangi bir müdahalede bulunulmadan incelendiği betimsel araştırmaların bir türü olması nedeni ile (Büyüköztürk, Kılıç Çakmak, Akgün, Karadeniz ve Demirel, 2017) ̈ğretmen adaylarının bilişötesi farkındalıkları ile duygusal zeka özellikleri arasındaki ilişkinin incelenmesinin amaçlandığı bu çalışmada bu araştırma modelinden yararlanılmıştır. Bununla beraber bu araştırma modeli; bağımsız değişken müdahalesinin bulunmadan, deneysel olmayan ve değişkenlerin doğal durumları ve tanımlamaları ile ölçülerek ilişkilendirildiği, nesnel temellerinin bulunduğu yaklaşımdır. Bu yaklaşım ile değişkenler arasında anlamlı bir ilişki olup olmadığını istatistiksel olarak bulgulayabilirken, 
değişkenler arasındaki bu ilişkinin nedenselliği üzerine bir çıkarım yapılabilmesi söz konusu değildir (Christensen, Johnson ve Turner, 2015).

\section{Örneklem}

Araştırmanın katılımcıları; İstanbul ilinde bulunan üniversitelerin Okul Öncesi Öğretmenliği Lisans Programı'na kayıtlı olan öğrencilerden basit rastgele örnekleme tekniğine uygun olarak belirlenmiştir. Bu örnekleme yöntemi, evrende bulunun her bireyin seçilme ihtimalinin eşit olduğu ve bunun sonucu olarak evrenin temsil gücünü yansıtma olasıllğııı arttıran bir yöntemdir (Aziz, 2011; Büyüköztürk, vd., 2017). Bu araştırmada İstanbul ilinde yer alan ilgili lisans programı bulunan devlet ve vakıf üniversitelerinin listesine ÖSYM tercih kılavuzundan ulaşılmıştır. Listede yer alan okullardan basit rastgele seçim yöntemiyle belirlenen okulların ilgili başkanlıkları ile elektronik posta aracıllğı̆la iletişim sağlanmıştır ve randevu alınarak uygulamalar yapılmıştır.

Tablo 1. Çalışma grubuna ilişkin betimleyici istatistik sonuçlanı

\begin{tabular}{|c|c|c|c|}
\hline & & $f$ & $\%$ \\
\hline \multirow{3}{*}{ Üniversite türü } & Devlet & 158 & 60.5 \\
\hline & Vakıf & 102 & 39.1 \\
\hline & Bilinmiyor & 1 & 0.4 \\
\hline \multirow{2}{*}{ Sınıf düzeyi } & Birinci sinif & 146 & 55.9 \\
\hline & Dördüncü sınıf & 115 & 44.1 \\
\hline \multirow{3}{*}{ Cinsiyet } & $K_{1 z}$ & 244 & 93.5 \\
\hline & Erkek & 16 & 6.1 \\
\hline & Bilinmiyor & 1 & 0.4 \\
\hline \multirow{4}{*}{ Sosyokültürel seviye } & $\mathrm{Alt}$ & 3 & 1.1 \\
\hline & Orta & 188 & 72.0 \\
\hline & Üst & 68 & 26.1 \\
\hline & Bilinmiyor & 2 & 0.8 \\
\hline \multirow{4}{*}{ Lise türü } & Anadolu Lisesi & 114 & 43.7 \\
\hline & Öğretmen Lisesi & 34 & 13.0 \\
\hline & Meslek Lisesi & 62 & 23.8 \\
\hline & Diğger & 51 & 19.5 \\
\hline \multirow{6}{*}{ Lise branş1 } & Eşit ağırlık & 129 & 49.2 \\
\hline & Çocuk gelişimi & 39 & 14.9 \\
\hline & Sayisal & 39 & 14.9 \\
\hline & Sözel & 35 & 4.6 \\
\hline & Diğger & 10 & 13.0 \\
\hline & Bilinmiyor & 9 & 3.4 \\
\hline \multirow{3}{*}{ Ön lisans programından mezun olma } & Evet & 15 & 5.7 \\
\hline & Hayır & 236 & 90.4 \\
\hline & Bilinmiyor & 10 & 3.8 \\
\hline \multirow{3}{*}{ Lisans programindan mezun olma } & Evet & 15 & 5.7 \\
\hline & Hayır & 237 & 90.8 \\
\hline & Bilinmiyor & 9 & 3.4 \\
\hline \multirow{5}{*}{ Üniversiteye yerleşme puan türü } & TS & 138 & 52.9 \\
\hline & YGS & 107 & 41.0 \\
\hline & DGS & 6 & 2.3 \\
\hline & Diğger & 8 & 3.1 \\
\hline & Bilinmiyor & 2 & 0.8 \\
\hline
\end{tabular}


Tablo 1'de gösterildiği üzere araştırmanın örneklemini; 2018-2019 eğitim öğretim y1lı bahar yarıyllinda devlet $(n=158)$ ve vakıf $(n=102)$ üniversitelerinde birinci $(n=146)$ ve dördüncü $(n=115)$ sınıfta öğrenim gören okul öncesi öğretmenliği lisans programına kayıtlı 21,03 yaş ortalamalı (ss=2,915; ranj=18-37) 261 öğrenci (nkız=244, nerkek=16, nbilinmiyor=1) oluşturmaktadır. Öğrencilerin kendilerine yönelik sosyokültürel seviye değerlendirmelerin; \%72,0's1 orta (norta=188) ve $\% 26,1$ '1 üst (nüst=68) ve \%1,1’i alt (nalt=3) olarak belirtmişlerdir. Programlara kayttlı öğrencilerin; \%43.7’si anadolu lisesi ( $\mathrm{n}=114), \% 23.8$ 'i meslek lisesi ( $\mathrm{n}=62), \% 13$ 'ü öğretmen lisesi $(\mathrm{n}=34)$ ve \%19.5'i diğer lise ( $\mathrm{n}=51$; açı lise, anadolu imam hatip lisesi, sosyal bilimler lisesi vb.) türlerinden; \%42.2'si eşit ağırlık, \%14.9’u çocuk gelişimi, \%14.9’u sayısal, \%4.6’s1 sözel puan türlerinden mezun olmuştur. Katılımcıların \%5.7’si ( $\mathrm{n}=15)$ bir ön lisans programından; \%5.7’si $(\mathrm{n}=15)$ bir lisans programından mezun olmuştur. Mevcut lisans programına öğrencilerin \%52.9’u TS ( $\mathrm{n}=138), \% 41.0$ ’1 YGS ( $\mathrm{n}=107), \% 2.3$ '̈̈ DGS ( $\mathrm{n}=6$ ) ve \%3.1'i diğer ( $\mathrm{n}=8$; YÖS, OSS, MF) puan türleri ile yerleşmişlerdir.

\section{Veri Toplama Araçları}

Kişisel Bilgi Formu: Araştırmacılar tarafından geliştirilen kişisel bilgi formu öğretmen adaylarının demografik bilgileri (yaş, cinsiyet, sosyokültürel durum v.b) ve akademik geçmişlerini (mezun olunan okullar, üniversiteye yerleşim puanlan v.b) saptamaya yönelik on bir sorudan oluşan bir formdur. Bunun yanı sıra öğrencilerin bilişötesi farkındalıkları ve duygusal zeka özelliklerine yönelik ön tahminde bulundukları sorular da formda yer alan sorulardandır.

Bilişötesi Farkındalık Envanteri(BFE): Bilişötesi Farkındalık Envanteri; 1994 yılında Shawn ve Dennison tarafindan "Metacognitive Awareness Inventory" başlığı ile geliştirilen 52 maddelik bir envanterdir. 5'li likert derecelendirme özelliğindeki envanter iki temel boyut (bilişin bilgisi, bilişin düzenlenmesi) ve sekiz alt boyuttan (açıklayıcı bilgi, prosedürel bilgi, durumsal bilgi, planlama, izleme, değerlendirme, hata ayıklama, bilgi yönetme) oluşmaktadır. Orijinal envanterin tümü için iç tutarlılık katsayıları .95 , alt boyutlar için .88 ile .93 arasında dağılım gösterdiği bulunmuştur. Envanterin Türkçeye uyarlama çalışması Akın, Abacı ve Çetin (2007) tarafindan 18-22 yaş aralığında bulunan üniversite öğrencileri örnekleminde yapılmıştır. Türkçeye uyarlamasında dilsel eş değerlik çalışmasının korelasyon katsayısı .89 olarak bulunmuş; uyarlamanın orijinal envanterin yapısındaki iki temel boyut ve sekiz alt boyut ile örtüştüğü bulunmuştur. Envanterin uyum geçerliliği .93, madde analizi test tekrar test korelasyonları .35 ile .65 arasında ve iç tutarlılık katsayısı .95 olarak tespit edilmiştir. 
Duygusal Zeka Özelliği Ölçeği - Kısa Formu (DZÖÖ-KF): Duygusal Zeka Özelliği Ölçeği - Kısa Formu (DZÖÖ-KF), 2000-2001 yıllarında Petrides ve Furnham tarafindan “Trait Emotional Intelligence Questionnaire - Short Form (TEIQue-SF)" başlığı ile geliştirilen 30 maddelik bir ölçektir. 7’li likert derecelendirme özelliğindeki ölçek dört alt boyuttan (iyi oluş, öz kontrol, duygusallık, sosyallik) oluşmaktadır. Orijinal ölçeğin tümü için iç tutarlılık katsayıları .95, alt boyutlar için .88 ile .96 arasında dağglım göstermektedir. Ölçeğin Türkçeye uyarlama çalışması Deniz, Özer ve Abacı (2013) tarafindan 17-32 yaş aralığında bulunan üniversite öğrencileri örnekleminde yapılmıştır. Türkçeye uyarlamasında dilsel eş değerlik ve geçerlilik çalışmasında pozitif yönlü korelasyon bulunmuş; açıklayıcı faktör analizi sonucunda madde sayısı yirmiye düşürülmüş ve dört faktörlü yapısı sürdürülmüştür. Ölçeğin test tekrar test korelasyonu .86 ve iç tutarllık katsayısı .81'dir. Ölçeğin; iyi oluş alt boyutu için iç tutarlılık katsayısı .72, öz kontrol alt boyutu için .70, duygusallık alt boyutu için .66 ve sosyallik alt boyutu için .70 olarak tespit edilmiştir.

\section{Verilerin Toplanmas1}

Araştırma verileri 2018-2019 eğitim öğretim yllı bahar yarıylında Şubat ve Mart ayı içerisinde toplanmıştır. Araştırmanın yürütülmesi için Etik Kurul izni alınmıştır. Bunun ardından araştırma verilerinin toplanması amacıyla ilk olarak araştırmacıların belirlediği üniversitelerin Anabilim Dalı Başkanlık'ları ile görüşülmüş araştırmanın amacından bahsedilerek araştırmaya katılım konusundaki görüşleri alınmıştır. Araştırmanın kabul edilmesinin ardından araştırmacılar öğretmen adaylarının derslerine katılarak, araştırmanın amacını ve araştırmada yer alan kavramları açılayarak anket formların nasıl doldurulacağını belirtmişlerdir. Anket formlarının öğretmen adayları tarafından doldurulması 10-15 dakika sürmüştür. Katılımcılardan her hangi bir kişisel bilgi alınmadan veriler toplanmış, uygulama sonunda teslim edilen formlara araştırmacılar ordinal sayılar vererek düzenlemiştir. Verilerin toplanması 13 eğitim öğretim günü içerisinde tamamlanmıştır.

\section{Verilerin Analizi}

Araştırmada elde edilen verilerin analizinde istatiksel paket analiz programı kullanılmıştır. Betimsel analizler sonucunda Bilişötesi Farkındalık Envanteri'nden elde edilen verilerinin normal dağıldığ1 görülmüş ve verilerin analizleri parametrik testler ile yapılmıştır. Duygusal Zeka Özelliği Ölçeği’nden elde edilen verilerinin normal dağılmadığı görülmüş ve analizler parametrik olmayan testler ile yapılmıştır (Kolmogorov-Smirnov, p>.05) (Durmuş, Yurtkoru ve Çinko, 2018).

Bilişötesi farkındalık verilerinin analizinde sınıf düzeyi ve üniversite türüne bağlı değişiklik gösterip göstermediğini belirlemek amacıyla parametrik analiz yöntemlerinden bağımsız grup t-testi ve 
yerleşilen puan türüne bağlı değissiklik gösterip göstermediğini belirlemek amacıyla parametrik olmayan analiz yöntemlerinden Kruskal Wallis H analizi yapılmıstır. Duygusal zeka özellikleri verilerinin analizinde sınıf düzeyi ve üniversite türüne bağlı değişiklik gösterip göstermediğini belirlemek amaciyla parametrik olmayan analiz yöntemlerinden Mann-Wihtney $U$ testi ve yerleşilen puan türüne bağlı değişiklik gösterip göstermediğini belirlemek amacıyla parametrik olmayan analiz yöntemlerinden Kruskal Wallis H analizi yapılmıştır. Öğretmen adaylarının bilişötesi farkındalıkları ile bilişötesi farkındalıklarına ilişkin tahmini değerleri arasındaki ilişkiyi belirlemek amacıyla parametrik analiz yöntemlerinden pearson analizi ve duygusal zeka özellikleri puanları ile duygusal zeka özelliklerine ilişkin tahmini değerleri arasındaki ilişkiyi belirlemek amacıyla parametrik olmayan analiz yöntemlerinden Spearman analizi yapılmıştır. Son olarak bilişötesi farkındalıkları ile duygusal zeka özellikleri arasındaki ilişkiyi belirlemek için parametrik olmayan analiz yöntemlerinden Spearman analizi yapılmıştır. Yapılan analizler sonucunda elde edilen korelasyon katsayısı düzeyleri, Çokluk ve arkadaşlarının (2018) belirttiği gibi +/-1.0 değerinde bulunması durumunda mükemmel, $+/-0.70$ ile +/-1.0 arasında değer alması durumunda yüksek ve +/-.30 ile +/-.69 arasında değer alması durumunda orta düzeyde ilişkili olduğu yönünde kabul edilmiştir.

\section{BULGULAR}

Araştırmanın bu kısmında; araştırmanın amacında yer alan okul öncesi öğretmen adaylarının bilişötesi farkındalık ve duygusal zeka özellikleri arasındaki ilişkiyi belirlemeye yönelik ilişki analizine ve alt amaçlarımızda yer alan öğretmen adaylarının kendi özelliklerine ilişkin tahminleri, üniversiteye yerleşme puan türleri, sınıf düzeyleri, öğrenim görmekte oldukları üniversite türleri ve mezun olunan lise türleri değişkenlerine ilişkin yapılan analizlerin sonuçlarına yer verilmektedir. $\mathrm{Bu}$ doğrultuda Tablo 2, 3 ve 4’te okul öncesi öğretmen adaylarının bilişötesi farkındalık puanları ile duygusal zeka özelliği puanları arasındaki ilişkilere, bilişötesi farkındalık puanları ile kendi tahmini değerlerine ve duygusal zeka özelliği puanları ile kendi tahmini değerlerine ilişkin ilişki analiz tablolarına yer verilmiştir.

Tablo 2: Bilişötesi Farkındalık Envanteri puanları ile Duygusal Zeka Özelliği Ölçeği puanlar arasındaki ilişkiler 


\begin{tabular}{|c|c|c|c|c|c|c|}
\hline $\begin{array}{l}\text { Toplam Çalışma } \\
\text { Grubu }(\mathrm{N}=261)\end{array}$ & $\begin{array}{l}\text { Duygusal Zeka } \\
\text { Ortalaması }\end{array}$ & İyi Oluş & $\begin{array}{l}\ddot{O}_{z} \\
\text { Kontrol }\end{array}$ & Duygusallık & Sosyallik & $\begin{array}{l}\text { Toplam } \\
\text { Duygusal } \\
\text { Zeka }\end{array}$ \\
\hline $\begin{array}{l}\text { Bilişötesi Farkındalık } \\
\text { Ortalaması }\end{array}$ & $.448^{* *}$ & $.403^{* *}$ & $.297 * *$ & $.294 * *$ & $.371 * *$ & $.365^{* *}$ \\
\hline Açıklayıcı Bilgi & $.489 * *$ & $.425^{* *}$ & $.300^{* *}$ & $.318^{* *}$ & $.447 * *$ & $.395^{* *}$ \\
\hline Prosedürel Bilgi & $.381 * *$ & $.370^{* *}$ & $.267 * *$ & $.189 * *$ & $.296^{* *}$ & $.348^{* *}$ \\
\hline Durumsal Bilgi & $.536^{* *}$ & $.473 * *$ & $.340^{* *}$ & $.328 * *$ & $.456^{* *}$ & $.472 * *$ \\
\hline Planlama & $.355^{* *}$ & $.338^{* *}$ & $.256^{* *}$ & $.234 * *$ & $.293^{* *}$ & $.263^{* *}$ \\
\hline İzleme & $.348^{* *}$ & $.330^{* *}$ & $.232^{* *}$ & $.228 * *$ & $.304 * *$ & $.284^{* *}$ \\
\hline Değerlendirme & $.326^{* *}$ & $.286^{* *}$ & $.208^{* *}$ & $.222 * *$ & $.283^{* *}$ & $.265^{* *}$ \\
\hline Hata Ayıklama & $.193^{* *}$ & $.175^{* *}$ & $.133^{*}$ & $.141 *$ & $.124 *$ & $.175^{*}$ \\
\hline Bilgi Yönetme & $.314^{* *}$ & $.344 * *$ & $.248^{* *}$ & $.205^{* *}$ & $.199 * *$ & $.210^{* *}$ \\
\hline
\end{tabular}

$*_{\mathrm{p}}<.05 ; *^{*} \mathrm{p}<.01$

Çalışma grubundaki öğretmen adaylarının bilişötesi farkındalıkları ve duygusal zeka özellikleri puanları arasındaki tahmini ilişkiyi belirlemek için yapılan spearman analizi sonucunda değişkenler arasında anlamlı ilişki bulunduğu sonucuna varılmıştır. Öğretmen adaylarının bilişötesi farkındalıkları ve duygusal zeka özelliği alt boyutlarına ilişkin sonuçlar incelendiğinde bilişötesi farkındalık boyutunun; duygusal zeka ortalaması $(r=.448 ; \mathrm{p}<01)$, iyi oluş $(\mathrm{r}=.403 ; \mathrm{p}<.01)$, sosyallik $(\mathrm{r}=.371 ; \mathrm{p}<.01)$ ve toplam duygusal zeka $(\mathrm{r}=.365 ; \mathrm{p}<.01)$ puanları ile orta düzeyde, öz kontrol ( $\mathrm{r}=.297 ; \mathrm{p}<.01)$ ve duygusallık $(\mathrm{r}=294 ; \mathrm{p}<.01)$ alt boyutları ile düşük düzeyde pozitif yönde anlamlı ilişkiler gösterdiği görülmüsstür. Açıklayıcı bilgi alt boyutunun, duygusal zeka özelliğinin tüm alt boyutları ile pozitif yönde orta düzeyde pozitif yönde anlamlı ilişkiler gösterdiği görülmüştür (rduygusalzekaort $=.489 ; \mathrm{p}<.01$, riyioluş=.425; $<<.01$, rözkontrol=.300; $\mathrm{p}<.01$, rduygusallık $=.318 ; \mathrm{p}<.01$, rsosyallik $=.447 ; \mathrm{p}<.01$, rduygusalzeka $=.395 ; \mathrm{p}<.01)$. Prosedürel bilgi alt boyutu incelendiğinde; duygusal zeka ortalaması ( $r=.381 ; \mathrm{p}<.01)$, iyi oluş ( $\mathrm{r}=.370 ; \mathrm{p}<.01)$ ve toplam duygusal zeka puanları $(\mathrm{r}=.348 ; \mathrm{p}<.01)$ ile orta düzeyde, öz kontrol( $\mathrm{r}=.267 ; \mathrm{p}<.01)$, duygusallık $(\mathrm{r}=.189 ; \mathrm{p}<.01)$ ve sosyallik $(\mathrm{r}=.296 ; \mathrm{p}<.01)$ alt boyutları ile düşük düzeyde pozitif yönde anlamlı ilişkiler gösterdiği görülmüsstür. Durumsal bilgi alt boyutu incelendiğinde ise, duygusal zeka özelliğinin tüm alt boyutları ile orta düzeyde pozitif yönde anlamlı ilişkiler gösterdiği görülmüştür (duygusal zeka ortalaması (rduygusalzaeka=.536; $\mathrm{p}<.01$ ), iyi oluş ( $\mathrm{r}=.473$; $\mathrm{p}<.01)$, öz kontrol ( $\mathrm{r}=.340 ; \mathrm{p}<.01)$, duygusallik ( $\mathrm{r}=.328 ; \mathrm{p}<.01)$, sosyallik $(\mathrm{r}=.456 ; \mathrm{p}<.01)$, toplam duygusal zeka $(\mathrm{r}=.472 ; \mathrm{p}<.01)$. Planlama alt boyutu incelendiğinde; duygusal zeka ortalamas1 $(\mathrm{r}=.355 ; \mathrm{p}<.01)$ ve iyi oluş $(\mathrm{r}=.338 ; \mathrm{p}<.01)$ alt boyutları ile orta düzeyde, öz kontrol $(\mathrm{r}=.256$; $\mathrm{p}<.01)$, duygusall1k $(\mathrm{r}=.234 ; \mathrm{p}<.01)$, sosyallik $(\mathrm{r}=.293 ; \mathrm{p}<.01)$ ve toplam duygusal zeka $(\mathrm{r}=.263$; $\mathrm{p}<.01)$ puanları ile düşük düzeyde pozitif yönde anlamlı ilişkiler gösterdiği görülmüştür. İzleme alt boyutu incelendiğinde; duygusal zeka ortalaması $(r=.348 ; \mathrm{p}<.01)$, iyi oluş $(\mathrm{r}=.330 ; \mathrm{p}<.01)$ ve sosyallik $(\mathrm{r}=.304 ; \mathrm{p}<.01)$ alt boyutları ile orta düzeyde, öz kontrol $(\mathrm{r}=.232 ; \mathrm{p}<.01)$, duygusallık $(\mathrm{r}=.228 ; \mathrm{p}<.01)$ ve toplam duygusal zeka $(\mathrm{r}=.284 ; \mathrm{p}<.01)$ puanları ile düşük düzeyde pozitif yönde anlamlı ilişkiler gösterdiği görülmüştür. Değerlendirme alt boyutu incelendiğinde; duygusal zeka 
ortalaması $(\mathrm{r}=.326 ; \mathrm{p}<.01)$ ile orta düzeyde, iyi oluş $(\mathrm{r}=.286 ; \mathrm{p}<.01)$, öz kontrol $(\mathrm{r}=.208 ; \mathrm{p}<.01)$, duygusallik $(r=.222 ; \mathrm{p}<.01)$, sosyallik $(r=.283 ; \mathrm{p}<.01)$ ve toplam duygusal zeka $(r=.265 ; \mathrm{p}<.01)$ puanları ile düşük düzeyde pozitif yönde anlamlı ilişkiler gösterdiği görülmüştür. Hata ayıklama puanlarının ise; duygusal zeka özelliğinin tüm alt boyutları ile düşük düzeyde pozitif yönde anlamlı ilişkiler gösterdiği görülmüştür ( $\mathrm{r}_{\text {duygusal zeka ortalaması }}=.193 ; \mathrm{p}<.01, \mathrm{r}_{\text {iyi oluṣ }}=.175 ; \mathrm{p}<.01, \mathrm{r}_{\text {öz kontrol }}=.133$; $\left.\mathrm{p}<.05, \mathrm{r}_{\text {duygusallik }}=.141 ; \mathrm{p}<.05, \mathrm{r}_{\text {sosyallik }}=.124 ; \mathrm{p}<.05, \mathrm{r}_{\text {toplam duygusal zeka }}=.175 ; \mathrm{p}<.05\right)$. Bilgi yönetme alt boyutu incelendiğinde; duygusal zeka ortalaması $(r=.314 ; \mathrm{p}<.01)$ ve iyi oluş $(\mathrm{r}=.344 ; \mathrm{p}<.01)$ alt boyutları ile orta düzeyde, öz kontrol ( $r=.248 ; \mathrm{p}<.01)$, duygusallık $(\mathrm{r}=.205 ; \mathrm{p}<.01)$, sosyallik $(\mathrm{r}=.199 ; \mathrm{p}<.01)$ ve toplam duygusal zeka $(\mathrm{r}=.210 ; \mathrm{p}<.01)$ puanları ile düşük düzeyde pozitif yönde ilişkiler gösterdiği görülmüştür.

Tablo 3: Bilişötesi Farkındalık Envanteri puanları ile okul öncesi öğretmen adaylarının bilişötesi farkındalıklarına ilişkin bulundukları tahmini puanlar arasındaki ilişkiler

\begin{tabular}{llll}
\hline Değişkenler & $\mathrm{N}$ & $\mathrm{r}$ & $\mathrm{p}$ değeri \\
\hline $\begin{array}{l}\text { Bilişötesi Farkındalık Puanları } \\
\text { Tahmini Değer }\end{array}$ & 251 & .287 & $.000^{* *}$ \\
\end{tabular}

$* * \mathrm{p}<.01$

Çalışma grubundaki öğretmen adaylarının bilişötesi farkındalıkları ve bilişötesi farkındalıklarına ilişkin tahmini değerleri arasındaki ilişkiyi belirlemek için yapılan pearson korelasyon analizi sonucunda pozitif yönde düşük düzeyde anlamlı ilisski bulunduğu sonucuna varılmıştır ( $\mathrm{r}=, 287$; $\mathrm{p}<0,01)$.

Tablo 4: Duygusal Zeka Özelliği Ölçeği puanları ile okul öncesi öğretmen adaylarının duygusal zeka özelliklerine ilişkin bulundukları tahmini puanlar arasındaki ilişki

\begin{tabular}{llll}
\hline Değişkenler & $\mathrm{N}$ & $\mathrm{r}$ & $\mathrm{p}$ değeri \\
\hline $\begin{array}{l}\text { Duygusal Zeka Özelliği Puanları } \\
\text { Tahmini Değer }\end{array}$ & 251 & .231 & $.000^{* *}$ \\
\hline
\end{tabular}

${ }^{* *} \mathrm{p}<.01$

Çalışma grubundaki öğretmen adaylarının duygusal zeka özellikleri ve duygusal zeka özelliklerine ilişkin tahmini değerleri arasındaki ilişkiyi belirlemek için yapılan spearman analizi sonucunda pozitif yönde düşük düzeyde anlamlı ilişki bulunduğu sonucuna varılmıştır $(r=.231 ; \mathrm{p}<0.01)$. 
Tablo 5 ve 11 arasında okul öncesi öğretmen adaylarının bilişötesi farkındalık puanları ile duygusal zeka özelliği puanlarının; üniversiteye yerleşme puan türü, sınıf düzeyi, üniversite türü ve mezun olunan lise türü değişkenlerine ilişkin fark analizi tablolarına yer verilmiştir.

Tablo 5: Okul öncesi öğretmen adaylarının Bilişötesi Farkındalık Envanteri ve Duygusal Zeka Özelliği Ölçeği’nden aldıkları puanların üniversiteye yerleşme puan türüne göre Kruskal Wallis $\mathrm{H}$ analizi sonuçları

\begin{tabular}{llllllll}
\hline Değişkenler & Yerleşilen puan türü & N & Ortalama & Kay kare & sd & p & Anlamlı Fark \\
\hline \multirow{4}{*}{ Bilişötesi Farkındalık } & YGS & 107 & 133.02 & & & YGS ile DGS \\
& TS & 138 & 124.69 & & & TS ile DGS \\
& DGS & 6 & 212.0 & 8.209 & 3 & $.042^{*}$ & Diğer ile DGS \\
& Diğer & 8 & 119.69 & & & & \\
& Toplam & 259 & & & & \\
\hline \multirow{5}{*}{ Duygusal Zeka Özelliği } & YGS & DS & 107 & 128.86 & & & YGS ile DGS \\
& DS & 138 & 127.63 & & & TS ile DGS \\
& Diğer & 6 & 222.25 & 9.506 & 3 & $.023 *$ & Diğer ile DGS \\
& Toplam & 8 & 117.00 & & & & \\
\hline
\end{tabular}

$*_{\mathrm{p}}<.05$

Çalışma grubundaki öğretmen adaylarının bilişötesi farkındalık puanlarının üniversiteye yerleşilen puan türü değişkenine göre karşılaştırılması için grup içi kişi sayısının 30’un altında kalması sebebi ile parametrik olmayan testlerden yararlanılmıştır. Yapılan Kruskal Wallis H analizi sonucunda istatistiksel olarak anlamlı bir farklılık olduğu sonucuna varılmıştır $(\chi 2=8.209 ; \mathrm{p}<.05)$. Oluşan bu farklılaşmanın hangi yerleşilen puan türleri arasında olduğunu tespit etmek amacıyla yapılan Mann Wihtney U testi sonuçlarına göre; üniversiteye DGS puan türü ile yerleşen öğretmen adaylarının diğer yerleşim türlerine göre anlamlı bir farklılık gösterdiği görülmüştür. Bu duruma paralel olarak öğretmen adaylarının duygusal zeka özelliği puanlarının üniversiteye yerleşilen puan türü değişkenine göre karşılaştırılması için yapılan Kruskal Wallis $\mathrm{H}$ analizi sonucunda istatistiksel olarak anlamlı bir farklılık olduğu sonucuna varılmıştır $(\chi 2=9.506 ; \mathrm{p}<.05)$. Oluşan bu farklılaşmanın hangi yerleşilen puan türleri arasında olduğunu tespit etmek amacıyla yapılan Mann Wihtney $U$ testi sonuçlarına göre; üniversiteye DGS puan türü ile yerleşen öğretmen adaylarının diğer yerleşim türlerine göre anlamlı bir farklılık gösterdiği görülmüştür.

Tablo 6: Okul öncesi öğretmen adaylarının Bilişötesi Farkındalık Envanteri’nden aldıkları puanların sınıf düzeyi değişkenine göre bağımsız grup t testi sonuçları

\begin{tabular}{ccccccc}
\hline Sinif düzeyi & $\mathrm{N}$ & $\mathrm{X}_{\text {ort }}$ & $\mathrm{ss}$ & $\mathrm{t}$ & $\mathrm{sd}$ & $\mathrm{p}$ \\
\hline 1. sinif & 146 & 3.758 & .534 & -1.943 & \multirow{2}{*}{251.655} & .064 \\
4. sinif & 115 & 3.882 & .498 & & & \\
\hline
\end{tabular}

$\mathrm{p}>.05$ 
Çalışma grubundaki öğretmen adaylarının bilişötesi farkındalık puanlarının sınıf düzeyi değişkenine göre karşılaştırılması için yapılan bağımsız grup t testi sonucunda üniversite türleri arasında anlamlı bir farklılık olmadığı sonucuna varılmıştır $(\mathrm{t}(251.655)=-1.943 ; \mathrm{p}>.05)$.

Tablo 7: Okul öncesi öğretmen adaylarının Bilişötesi Farkındalık Envanteri’nden aldıkları puanların üniversite türü değişkenine göre bağımsız grup $t$ testi sonuçları

\begin{tabular}{ccccccc}
\hline Üniversite türü & $\mathrm{N}$ & $\mathrm{X}_{\text {ort }}$ & $\mathrm{ss}$ & $\mathrm{t}$ & $\mathrm{sd}$ & $\mathrm{p}$ \\
\hline Devlet & 158 & 3.802 & .510 & \multirow{2}{*}{-.512} & \multirow{2}{*}{207.079} & .609 \\
Vakıf & 102 & 3.836 & .539 & & & \\
\hline
\end{tabular}

$\mathrm{p}>.05$

Çalışma grubundaki öğretmen adaylarının bilişötesi farkındalık puanlarının üniversite türü değişkenine göre karşılaştırılması için yapılan bağımsız grup t testi sonucunda türleri arasında anlamlı bir farklılık olmadığı sonucuna varılmıştır $(\mathrm{t}(207.079)=-.512 ; \mathrm{p}>.05)$.

Tablo 8: Okul öncesi öğretmen adaylarının Bilişötesi Farkındalık Envanteri’nden aldıkları puanların mezun olunan lise türüne göre ANOVA sonuçları

\begin{tabular}{cccccc}
\hline Değişkenler & $\mathrm{N}$ & $\mathrm{X}_{\text {ort }}$ & ss & $\mathrm{F}$ & $\mathrm{P}$ \\
\hline Meslek Lisesi & 62 & 3.89777 & .557949 & & .543 \\
Öğretmen Lise & 34 & 3.82440 & .468316 & .720 & \\
Anadolu Lisesi & 114 & 3.77772 & .487153 & & \\
Diğer & 51 & 3.78170 & .584506 & .521715 & \\
Toplam & 261 & 3.81309 & & \\
\hline
\end{tabular}

$\mathrm{p}>.05$

Çalışma grubundaki öğretmen adaylarının Bilişötesi Farkındalık Envanteri'nden aldıkları puanlar mezun olunan lise türüne göre karşılaştırılması için yapılan ANOVA sonucunda anlamlı bir farklılık olmadığ1 sonucuna varılmıştır $(F(3)=.720 ; \mathrm{p}>.05)$.

Tablo 9: Okul öncesi öğretmen adaylarının Duygusal Zeka Özelliği Ölçeği’nden aldıkları puanların üniversite türü değişkenine göre Mann-Whitney U testi sonuçları

\begin{tabular}{cccccc}
\hline Üniversite türü & $\mathrm{N}$ & $\mathrm{X}_{\text {ort }}$ & $\mathrm{U}$ & $\mathrm{Z}$ & $\mathrm{P}$ \\
\hline Devlet & 158 & 125.16 & 7214.500 & -1.425 & .154 \\
Vakıf & 102 & 138.77 & & \\
\hline
\end{tabular}

$\mathrm{p}>.05$

Çalışma grubundaki öğretmen adaylarının duygusal zeka özelliği puanlarının üniversite türü değişkenine göre karşılaştırılması için yapılan Mann-Whitney U testi sonucunda cinsiyetler arasında anlamlı bir farklılık olmadığı sonucuna varılmıştır (U=7214.500; $\mathrm{p}>.05)$.

Tablo 10: Okul öncesi öğretmen adaylarının Duygusal Zeka Özelliği Ölçeği’nden aldıkları puanların sınıf düzeyi değişkenine göre Mann-Whitney U testi sonuçları

\begin{tabular}{|c|c|c|c|c|c|}
\hline 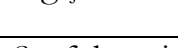 & 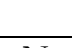 & 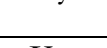 & 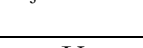 & 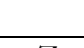 & 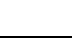 \\
\hline Inif düze & $\mathrm{N}$ & $\mathrm{X}_{\text {ort }}$ & \multirow{2}{*}{8047500} & \multirow{2}{*}{574} & \multirow{2}{*}{$x^{2}$} \\
\hline 1. sinif & 146 & 128.62 & & & \\
\hline
\end{tabular}


Çalışma grubundaki öğretmen adaylarının duygusal zeka özelliği puanlarının sınıf düzeyi değişkenine göre karşılaştırılması için yapılan Mann-Whitney U testi sonucunda cinsiyetler arasında anlamlı bir farklılık olmadığı sonucuna varılmıştır $(\mathrm{U}=8047.500 ; \mathrm{p}>.05)$.

Tablo 11: Okul öncesi öğretmen adaylarının Duygusal Zeka Özelliği Ölçeğł’nden aldıkları puanların mezun olunan lise türüne göre Kruskal Wallis H analizi sonuçları

\begin{tabular}{ccccccc}
\hline & Değişkenler & $\mathrm{N}$ & Ortalama & Kay kare & sd & $\mathrm{p}$ \\
\hline Meslek Lisesi & 62 & 140.15 & & & \\
& Öğretmen Lise & 34 & 126.49 & & & \\
& Anadolu Lisesi & 114 & 133.02 & 2.541 & 3 & .468 \\
& Diğer & 51 & 118.37 & & & \\
& Toplam & 261 & & & & \\
\hline p>.05 & & & & &
\end{tabular}

Çalışma grubundaki öğretmen adaylarının duygusal zeka özelliği puanlarının mezun olunan lise türü değişkenine göre karşılaştırılması için yapılan Kruskal Wallis $\mathrm{H}$ analizi sonucunda istatistiksel olarak anlamlı bir farklılık olmadığı sonucuna varılmıştır $(\chi 2=2.541 ; \mathrm{p}>.05)$.

\section{SONUÇ ve TARTIŞMA}

Araştırmanın bu bölümünde elde edilen bulgulara ilişkin sonuçlara, alan yazında bulunan bilgiler 1şığında tartışmalara ve önerilere yer verilmektedir.

Araştırma sonucunda ilk olarak araştırmadan elde edilen bulguda çalışma grubunda yer alan öğretmen adaylarının bilişötesi farkındalıkları ile duygusal zeka özelliği puanlarının pozitif yönde orta düzeyde anlamlı bir ilişkisinin bulunduğu ortaya çıkmıştır. Buradan yola çıkarak öğretmen adaylarının bilişötesi farkındalığına ilişkin düzeyleri arttıkça duygusal zeka özelliği puanlarının da arttığı söylenebilmektedir. Alan yazında bu iki kavramın ilişkisini açılayan üniversite öğrencileri ile yapılan araştırmada duygusal zeka ve bilişötesi arasında bilişötesi farkındalık boyutunda pozitif yönde anlamlı ilişki saptayan bir çalışma bulunurken (Byzova ve Perikova, 2019) tersi durumu bildiren araştırma bulgusu bulunamamışır. Yapılan çalışmadan elde edilen bulguları Byzova ve Perikova (2019) duygusal zekanın bir bilişötesi beceri gibi kuramsallaştırılması ve öz düzenleme becerileri ile yorumlanabileceğini bildirmektedir. Benzeri şekilde yapılan bu araştırmanın sonuçlarından da bilişötesi farkındalık ve duygusal zeka arasında kuramsal anlamda bağlantıların olabileceği ve bu iki beceriye etki eden ortak faktörlerin olabileceği düşünülmektedir. Duygusal zekanın öz düzenleme becerilerini kapsayan süreçler içermesi (Goleman, 1999) ve bilişötesinin öz düzenleme becerisinde önemli görülmesi ise bu ilişkinin öz düzenleme ile ilişkili olabileceğini çağrıştırmaktadır. Nitekim Boekaerts (2007) oluşturduğu “çift yönlü işleme” öz düzenleme modelinde öğrencilerin verilen görevler ile bireysel hedefleri, değerleri ve gereksinimleri 
uyuştuğunda yaptıklarından zevk aldıklarını, gerekli bilişsel ve motivasyonel stratejileri geliştirdikleri ve de çaba gösterdiklerini açıklamaktadır. Bu durum bilişsel süreçler ile beraber duyguların da önemli olduğunu vurgulamaktadır. Benzeri şekilde Weiner (2000) davranışın sergilenmesinde duyguların beraber olduğu düşüncelerin etkili olduğunu bildirmektedir. Bir diğer yandan Brinol, Petty ve Rucker (2006) yaptıkları çalışmada bilişötesinin duygusal tecrübeler ile ilişkili olduğunu açıklamıştır. Tüm bu bilgiler göz önünde bulunduğunda duygusal zeka ve bilişötesi bağlamında ilişkisel durumların bulunabildiği görülmektedir.

Çalışma grubunda yer alan öğretmen adaylarının bilişötesi farkındalıklarına ilişkin tahminleri ve bilişötesi farkındalı̆̆ı envanter düzeyleri ile duygusal zeka özelliklerine ilişkin tahminleri ve duygusal zeka özelliği puanlarının pozitif yönde düşük düzeyde anlamlı bir ilişkisinin bulunduğu ortaya çıkmıştır. Bu bulgudan yola çıkarak öğretmen adaylarının bilişötesi farkındalık ve duygusal zeka özelliklerine ilişkin aldıkları puanların yüksek ya da düşük olmasının öğretmen adaylarının bu özelliklerine ilişkin bulundukları tahminleri ile ilişkili olduğunu göstermektedir fakat ilişkinin düşük düzeyde olması ölçümlerden yüksek veya düşük puan alan adayların tahminleri arasında paralel olmayan durumlar olduğunu da göstermektedir. Bilişötesi farkındalıkları düşük olan ve elde edilen bulgu ile paralellik gösteren kişilerin kendilik algılarının yüksek olduğu düşünülebilir. Kendilik alg1sı; kendi duyguları, tutumları, inançları ve diğer içsel durumlarıyla ilgili bilgiyi kendi davranışlarını gözlemleyerek edinilmesi olarak tanımlanmaktadır. (Bem ve McConnell, 1970 akt. Özen,2014). Nitekim iki bulgunun benzer yönde çıkması kişilerin kendilerini tanıyor olduklarını gösterdiği söylenebilir. Ancak alan yazında bu konu üzerine yazılmış herhangi bir bulguya rastlanmamıştır.

Çalışma grubundaki öğretmen adaylarının üniversiteye yerleşme puan türü ile değerlendirildiği durumda ise Bilişötesi Farkındalık Envanterive duygusal zeka özelliği puanlarının DGS puan türü ile yerleşen öğretmen adayları lehine pozitif yönde anlamlı bir farklılık gösterdiği ortaya çıkmıştır. Bu bulgudan yola çıkarak üniversiteye yerleşme puan türünün bilişötesi farkındalık ve duygusal zeka puanlarının ortalamaları üzerinde etki sahibi olduğu söylenebilmektedir. Farklılık gösteren adaylar üniversitelerin Meslek Yüksekokullarında ön lisans eğitimi görmüş ve eğitimini lisans derecesinde devam ettirebilmek için ön lisans başarı puanları ve DGS puan kriterlerini sağlayarak tercihlerde bulunarak başarılı olmuş adaylardır (ÖSYM, 2019). Bu sistem ile yerleşen adayların bilişsel ve duygusal deneyimlerinin diğer türlerden yerleşen adayların deneyimlerine oranla daha fazla olabileceği ve üniversiteye yerleşme sürecindeki yaşantılarının, içinde bulundukları duruma yönelik geliştirdikleri stratejilerin bilişötesi ve duygusal zeka özellikleri üzerinde etkili olabileceği düşünülmektedir. Örneğin; duygularını kontrol etmede daha başarılı olabilirler. Bunun yanında bilişötesi farkındalıkları da daha yüksek olabilir. 
Araştırmadan elde edilen bir diğer bulguda ise; çalışma grubunda yer alan öğretmen adaylarının Bilişötesi Farkındalık Envanterive duygusal zeka özelliği puanlarının üniversite türü değisskenine göre anlamlı bir farklılık oluşturmadığı ortaya çıkmıştır. Farklılaşmanın bulunmaması ile üniversite türünün bilişötesi farkındalık ve duygusal zeka puanları ortalamaları üzerinde etki sahibi olmadığ1 söylenebilmektedir. Okul öncesi öğretmenliği lisans programında okuyan öğrencilerin özel veya devlet üniversitesi fark etmeksizin aynı puan türü ve benzer eğitim geçmişleri ile yerleştikleri görülmektedir (YÖK Atlas, 2019). İki üniversite türünde de öğrenim gören öğretmen adaylarının duygusal ve bilişötesi farkındalıklarında herhangi bir farklılık bulunmaması öğretmen adaylarının üniversiteye yerleşme sürecinde merkezi sınav yerleştirmelerinde aynı puan türü ile tercihte bulunmaları ve buna uygun olarak üniversite tercihi yapan adayların benzer özelliklere sahip olduğu veya üniversite eğitiminin öğretmen adaylarını benzer özelliklerde geliştirdiğini düşünülebilir. Üniversite türü değişkenine göre karşılaştırma yapılabilecek çalısma bulunmaması sebebi ile bu sonuçların karşılaştırılması yapılamamışırı.

Çalışma grubunda yer alan öğretmen adaylarının Bilişötesi Farkındalık Envanterive duygusal zeka özelliği puanlarının sınıf düzeyi değişkenine göre anlamlı bir farklılık oluşturmadığı ortaya çıkmıştır. Bu bulgudan yola çıkarak sınıf düzeyinin bilişötesi farkındalık ve duygusal zeka puanları ortalamaları üzerinde etki sahibi olmadığı söylenebilmektedir. Alan yazında, okul öncesi öğretmenlerinin bilişötesi farkındalıklarının sınıf düzeyi değişkenine göre karşılaştırmasında dördüncü sınıf öğrencilerinin lehinde bulgular mevcut olmak ile beraber (Özsoy ve Günindi, 2011) birinci ve dördüncü sınıf düzeyinde öğretmen adaylarının puanlarının paralellik gösterdiği yönünde bulgular da mevcuttur (Demirel, Aşkın ve Yağcı, 2015). Duygusal zeka ile ilgili yapılan çalışmalarda eğitim fakültesi öğrencilerinin sınıf düzeylerince anlamlı farklılık göstermediği yönünde bulgular mevcut iken (Kız1l, 2012) duygusal zeka özelliklerinden sosyallik ve duygusallık alt boyutları haricinde dördüncü sınıf lehinde farklılaştığı bulunmuştur (Özdemir, 2015). Araştırmamızın sonuçları alan yazında yapılan bulgular ile desteklenebilirken, elde ettiğimiz bulguların tersi yönünde araştırma sonuçları da görülmektedir. Bu farklılığın uygulama yapılan çalışma gruplarından ve bu grupların lisans eğitimi süreçlerindeki deneyimlerinden farklılaştı̆̆1 düşünülmektedir. Konu ile ilgili yapılan çalışmalarda geniş çalışma gruplarına yer veren ve öğrencilerin lisans eğitimi deneyimlerinin de betimlendiği araştırmalara ihtiyaç duyulmaktadır.

Son olarak, çalışma grubundaki öğretmen adaylarının bilişötesi farkındalık puanları ve duygusal zeka puanlarının mezun oldukları lise türü değişkenine göre anlamlı bir farklılık oluşturmadığı ortaya çıkmıştır. Bu bulgudan yola çıkarak mezun olunan lise türünün bilişötesi farkındalık ve duygusal zeka puanları ortalamaları üzerinde etki sahibi olmadığı söylenebilmektedir. Alan yazında, öğretmen 
adaylarının bilişötesi farkındalıklarının mezun olunan lise türü değişkenine göre karşılaştırılmasında anlamlı farklılıkların olmadığı yönünde bulgular bulunmaktadır (Özsoy ve Günindi, 2011; Cihanoğlu, 2012; Demirel, Aşkın ve Yağc1, 2015). Bu durum araştırmadan elde eden bulguları desteklemektedir. Elde edilen bu sonuç ve önceki araştırma bulguları aynı lisans programına yerleşmiş öğretmen adaylarının lise türü, lisede aldıkları eğitim ve lise yaşantılarının bilişötesi ve duygusal zeka özelliklerine etki etmediğini açklamaktadır. $\mathrm{Bu}$ durum göz önünde bulundurulduğunda bilişötesi ve duygusal zeka özelliğinin lise eğitiminden ve öğrencilerin farklı lise türlerinde edindikleri tecrübelerden bağımsız olabileceği söylenebilir. Bu durumda öğrencilerin bilişötesi ve duygusal zeka özelliklerine etki eden geçmiş yaşantılara dönük faktörlerin belirlenmesine ihtiyaç duyulduğunu göstermektedir.

Aşağıda araştırma bulgularından hareket ile araştırmacılara sonraki çalışmalar için önerilerde bulunulmuştur:

Öğretmen adaylarının bilişötesi ve duygusal zeka özelliklerinin ilişkilerini saptamaya çalışan bu araştrımada ilişki düzeyinde farklılık tespit edilmiştir ancak araştırmada yer alan öğretmen adayı sayısı yordama analizi yapılabilmesi için sınırlayıcıdır. Ancak yine de daha sonraki yordayıcı faktörlere ilişkin farklılık gösteren örneklem grupları (farklı lisans programları, üniversiteler, öğretmenler ve öğretmen adayları gibi) ile çalışmalar yapılmasına bir referans olma yeterliliğindedir. Bu nedenle örneklem sayısı arttırılarak ve farklı profillerle yapılacak biliş ötesine ve duygusal zekaya ilişkin yordayıcı faktörlerle ilgili araştırmalar bu kavramların öğretmen adayları profilinde betimlenmesinde faydalı olabileceğinden önerilebilir. Yapılan bu araştırmada sınıf düzeyi değişkenine göre duygusal zeka ve bilişötesi farkındalıklarından elde edilen sonuca göre anlamlı farklılık bulunmaması nedeniyle uygulayıcılara; öğretmen adaylarının eğitim süreçlerinde duygusal zeka ve bilişötesi özelliklerine ilişkin becerilerini geliştirebilecekleri eğitim programlarının uygulanması, ders içeriklerinin düzenlenmesi ve bu alanlarda farkındalıklarının artmasına olanak sağlayıcı faaliyetlerde bulunması önerilmektedir. Bunun yanı sıra araştırmacılara da uygulanan eğitim programları ile ilişkili bilişötesi ve duygusal zeka becerilerinin geliştirilmesine yönelik pilot uygulamalar yaparak sonuçların değerlendirilmesi önerilmektedir. Adayların bilişötesi farkındalıkları ve kendi bilişötesi farkındalık özelliklerine ilişkin bulundukları tahmini puan arasında pozitif yönlü ilişkinin bulunması sonucuna yönelik olarak araştırmacılara, bir sonraki çalışmalarda kendilik algısı üzerine de çalışmalar yaparak düşük bilişötesi farkındalığa sahip adayların, kendilerine yönelik tahminlerine ilişkin tutarlılık arasındaki çelişkili durumun araştırılması önerilmektedir 


\section{KAYNAKÇA}

Akın A., Abacı R. ve Çetin, B. (2007). The validity and reliability study of the Turkish version of the metacognitive awareness inventory. Educational Science: Theory ve Practice, $7(2), 655-680$.

Aziz A. (2011) Sosyal Bilimlerde Araştırma Yöntemleri ve Teknikleri. Ankara: Nobel Akademi Yayıncilik.

Barchard K. A. (2003). Does emotional intelligence assist in the prediction of academic success? Educational and psychological measurement , 63(5), 840-858.

Baş F. ve Özturan Sağırlı M. (2017). Türkiye'de eğitim alanında üstbiliş odaklı yapılan makalelere yönelik bir içerik analizi. Eğitim ve Bilim, 42(192), 1-18.

Boekaerts, M. (2007). Understanding students' affective processes in the classroom. P. A. Schutz, \& R. Pekrun içinde, Emotion in education (s. 37-56). San Diego: Academic Press.

Brinol, P., Petty, R. E. ve Rucker, D. D. (2006). The role of meta-cognitive processes in emotional intelligence. Psicothema, 18, 26-33.

Brown A. (1987). Metacognition, executive control, self-regulation, and other more mysterious mechanisms. F. Weinert ve R. Kluwe (Ed.) içinde, Metacognition, motivation, and understanding (s. 65-116). NJ: Lawrence Erlbaum.

Büyüköztürk Ş., Kılıç Çakmak E., Akgün Ö. E., Karadeniz Ş. ve Demirel F. (2017). Bilimsel Araştırma Yöntemleri. Ankara: Pegem Akademi Yayıncılık.

Byzova V. M. ve Perikova E. I. (2019) Identifying emotional intelligence and metacognitive awareness among university student. International Conference on Research in Psychology. London, United Kingdom, 7-9 Mart 2019, pp. 1-12.

Christensen L. B., Johnson R. B. ve Turner L. A. (2015) Research Methods, Design, And Analysis. England: Pearson Education Limited.

Cihanoglu M. O. (2012). Metacognitive awareness of teacher candidates. Procedia-Social and Behavioral Sciences, 46, 4529-4533.

Collaborative for Academic, Social, and Emotional Learning (CASEL). 03 Haziran 2019 tarihinde https://casel.org/ adresinden erişildi.

Curci A., Lanciano T. ve Soleti E. (2014). Emotions in the clasroom: The role of teachers' emotional intelligence ability in predicting students' achievement. American Journal of Psychology, 127(4), 431-445.

Çetinkaya P. ve Erktin E. (2002). Assessment of metacognition and its relationship with reading comprehension, achievement, and aptitude. Boğaziçi Üniversitesi Eğitim Dergisi, 19(1), 1-11. 
Çokluk, Ö., Şekercioğlu, G., \& Büyüköztürk, Ş. (2018). Sosyal bilimler için çok değişkenli istatistik SPSS ve LISREL uygulamaları (3. basım). Ankara: Pegem Akademi.

Çiltaş A. (2011). Eğitimde öz-düzenleme öğretiminin önemi üzerine bir çalışma. Mehmet Akif Ersoy Üniversitesi Sosyal Bilimler Enstitüsü Dergisi, 3(5) ,1-11.

Demirel M., Aşkın İ. ve Yağcı E. (2015). An investigation of teacher candidates' metacognitive skills. Procedia-Social and Behavioral Sciences, 174, 1521-1528.

Deniz M. E., Özer E. ve Işık E. (2013). Trait emotional intelligence questionnaire-short form: Validity and reliability studies. Education and Science, 38 (169), 407-419.

Doğan A. (2013). Üstbiliş ve üstbilişe dayalı öğretim. Middle Eastern ve African Journal of Educational Research, 3(6), 6-20.

Doğan Kılıç E. ve Önen Ö. (2009). Öğretmen adaylarının duygusal zeka düzeyleri ve etik muhakeme yetenekleri. Uluslararası İnsan Bilimleri Dergisi, 6(1), 123-163.

Dolev N. ve Leshem S. (2016). Teachers' emotional intelligence: The impact of training. The Journal of Emotional Education, 8(1), 75-94.

Duffy, G. G., Miller, S., Parsons, S., \& Meloth, M. (2009). Teachers as metacognitive professionals. D. J. Hacker, J. Donlosky, \& A. C. Graesser (Ed.) içinde, Handbook of metacognition in education (s. 240-257). New York: Routledge.

Dunlosky J. ve Metcalfe J. (2009). Metacognition. USA: Sage Publications.

Fernandez-Berrocal P. ve Ruiz D. (2008). Emotional intelligence in education. Electronic journal of research in educational psychology, 421-436.

Flavell, J. (1979). Metacognition and cognitive monitoring: A new area of cognitive-developmental inquiry. American Psychologist, 34(10), 906-911.

Fleming S. M., Dolan R. J. (2012). The neural basis of metacognitive ability. Philosophical Transactions of The Royal Society B Biological Sciences 367(1594):1338-49.

Goleman, D. (1999). Working with Emotional Intelligence. New York: Bantam Books .

Gross, J. J. (2003). Emotion regulation: Affective, cognitive and social consequences. Psychophsiology, 39(3), 281-291.

Gunzenhauser, G. W., Lindner, R., Harris, B., \& Kersting, J. (1994). INTASC's model standards for beginning teacher licensing and development: One model for teacher preparation programming. Western İllinois University.

Hacker D. J., Dunlosky J. ve Graesser A. C. (Ed.) içinde, Handbook of metacognition in education (s.240-256). Routledge.

Imel, S. (2002). Metacognitive skills for adult learning. Trends and issues alert. Washington: Office of Educational Research and Improvement. 
Işık, A., Çiltaş, A. ve Baş, F. (2010). Öğretmen yetiştirme ve öğretmenlik mesleği. Atatürk Üniversitesi Sosyal Bilimler Enstitüsü Dergisi, 14(1), 53-62.

Jaeger A., Bresciani M. ve Ward, C. (2003). Predicting persistence and academic performance of first year students: An assessment of emotional intelligence and non-cognitive variables. Association for the study of higher education (ASHE) national conference. Portland: OR.

Karakelle S. (2016). Bildiğimi bildiğimi nasıl bilirim: Üstbilişsel süreçlerin yaşam boyu değişimi. Aydın, T. Göksun, A. Küntay ve D. Tahiroğlu (Ed.) içinde, Aklın Çocuk Hali: Zihihn Gelişimi Araştırmaları (s. 189-210). İstanbul: Koç Üniversitesi Yayınları.

Kızıl Z. (2012). Eğitim bilimleri fakültesi öğrencilerinin duygusal zekâlarının çeşitli değişkenler açısından incelenmesi. Yayımlanmamış yüksek lisans tezi, Ankara Üniversitesi, Ankara.

Krueger F., Barbey A. K., McCabe K., Strenziok M., Zamboni G., Solomon J., Raymont V., ve Grafman J. (2009). The neural bases of key competencies of emotional intelligence. PNAS, 106(52), 22486-22491

Martinez M. E. (2006). What is metacognition? Phi Delta Kappan, 87(9), 696-699.

Mohzan M., Hassan N. ve Halil N. (2013). The influence of emotional intelligence on academic achievement. Procedia-Social and Behavioral Sciences, 90, 303-312.

Oktay, A., \& Özcan, Z. Ç. (2017). Biliş üstü beceriler. Ankara: Pegem Akademi.

Orta Doğu Teknik Üniversitesi Eğitim Bilimleri Bölümü. (2018). Eğitim Bilimleri Bölümü’nün Yükseköğretim Kurulu (YÖK) tarafindan 16 Mayıs 2018 tarihinde açıklanan öğretmen yetiştirme lisans programlarına ilişkin görüşleri. Temmuz 21, 2020 tarihinde http://eds.metu.edu.tr/en/egitim-bilimleri-bolumu-nunyuksekogretim-kurulu-yok-tarafindan-16-mayis-2018-tarihinde-aciklanan adresinden alınd 1

Öğrenci Seçme ve Yerleştirme Merkezi (ÖSYM). 28 Aralı 2019 tarihinde https://dokuman.osym.gov.tr/pdfdokuman/2019/DGS/kilavuz26042019.pdf adresinden erişildi.

Özcan, Z. Ç. (2007). Sınıf öğretmenlerinin derslerinde biliş üstü beceri geliştiren stratejileri kullanma düzeylerinin incelenmesi. Yayınlanmamış yüksek lisans tezi. Marmara Üniversitesi, İstanbul

Özdemir M. (2015). Eğitim fakültesi öğrencilerinin duygusal zekaları ile yaşam doyumlarının incelenmesi. Yayımlanmamış yüksek lisans tezi. Atatürk Üniversitesi, Erzurum.

Özen Y. (2014). Kendilik, kendilik alg1sı ve kendilik algısına bağlı psikosomatik bozukluklara sosyal psikolojik bir bakış. Sosyal Bilimler E-Dergisi, 40.

Özsoy G. ve Günindi Y. (2011). Prospective preschool teacher's metacognitive awareness. İlköğretim Online, 10(2), 430-440, 2011. 
Pellitteri J. ve Smith B. (2007). Building academic success on social and emotional learning: What does the researcher say? J. E. Zins, R. P. Weissberg, M. C. Wang ve H. J. Walberg (Ed.), Reading ve Writing Quarterly, 23(2), 197-2002. doi: https://doi.org/10.1080/10573560600992837

Pintrich ve M. Zeidner içinde, The handbook of self-regulation (s. 13-39). Academic Press. doi: https://doi.org/10.1016/B978-0-12-109890-2.X5027-6

Salovey P. ve Mayer J. (1990). Emotional Intelligence. Imagination, Cognition and Personality, 9(3), 185-211.

Sarısoy, B., \& Erişen, Y. (2018). Öğretmenler için duygusal zekâ becerileri eğitim programının tasarlanması, uygulanması ve değerlendirilmesi. İlköğretim Online, 17(4), 21882215.

TEDMEM. (2018). Öğretmenlik meslek kanunu öneri metni. Ankara: Türk Eğitim Derneği.

Tüysüz C., Karakuyu Y. ve Bilgin İ. (2008). Öğretmen adaylarının üstbiliş düzeylerinin belirlenmesi. Abant İzzet Baysal Üniversitesi Sosyal Bilimler Enstitüsü Dergisi. 2 (17) , 147 158 . doi: 10.11616/AbantSbe.225

Ünlü B., Ezberci Çevik E. ve Kurnaz M. A. (2016). Okul öncesi öğretmen adaylarının duygusal zekalarının çeşitli değişkenler açısından incelenmesi. Kastamonu Education Journal, 24(5), 2425.

Valente S., Monteiro A. ve Lourenço A. (2019). The relationship between teachers' emotional intelligence and classroom discipline management. Psychol Schs, 56(5), 741-750

Weiner, B. (2000). Intrapersonal and interpersonal theories of motivation from an attributional perspective. Educational Psychology Review, 12(1-14)

Wells A. (2002). Emotional disorders and metacognition: Innovative cognitive therapy. New York, NY: John Wiley ve Sons.

Wheaton, A. (2012). Metacognition and emotional intelligence. Australian Educational Leader, 34(1), 38-41.

Yaralı, K. T. ve Aytar, A. G. (2017). Okul öncesi dönem çocuklarının davranışlarının öz düzenleme becerileri yönünden incelenmesi. Mersin Üniversitesi Eğitim Fakültesi Dergisi, 13(3), 856-870. DOI: http://dx.doi.org/10.17860/mersinefd.291209

Yüksek Öğretim Kurumları Progran Atlası (YÖK Atlas). 28 Aralık 2019 tarihinde https://yokatlas.yok.gov.tr/netler-tablo.php?b=20062 adresinden erişildi.

Yüksek Öğretim Kurumu. (2018). Okul öncesi öğretmenliği lisans programı. Ankara: Yüksek Öğretim Kurumu.

Zimmerman B. (2000). Attaining self-regulation: A social cognitive perspective. M. Boekaerts, P. R. Pintrich (Ed.) içinde, Handbook of self-regulation (s. 13-39). Academic Press.

Zimmerman B. J. (1989). A social cognitive view of self-regulated academic learning. Journal of Educational Psychology, 81(3), 329-339. DOI:0.1037/0022-0663.81.3.329 